\title{
STRATEGI UNTUK MENGATASI SERTA MENGELOLA RASA STRESS DI MASA PANDEMI COVID-19 BAGI MAHASISWA
}

\author{
STRATEGIES TO ADDRESS AND MANAGE STRESS IN THE COVID-19 PANDEMIC \\ TIME FOR COLLEGE STUDENTS \\ Azkia Noryasyifa Ramadhania \\ Program Studi Psikologi, Fakultas Kedokteran, Universitas Lambung Mangkurat \\ E-mail : azkia.nr06@gmail.com
}

\begin{abstract}
ABSTRAK
Saat ini dunia tengah mengalami kondisi menggemparkan dimana sebuah virus yang disebut dengan Covid-19 ini menyebar dengan cepat hingga mampu membunuh banyak orang tanpa memandang umur. Oleh karena itu pemerintah membuat kebijakan untuk melakukan social distancing guna mengendalikan penyebaran virus, dimana masyarakat dianjurkan untuk tetap berada di rumah dan melakukan aktivitas, baik itu belajar maupun bekerja dari rumah. Selama melakukan work from home tentunya masyarakat, tanpa terkecuali mahasiswa semakin lama akhirnya akan merasa jenuh dikarenakan lebih banyak menghabisakan waktu di rumah dan jarang keluar, bahkan untuk bertemu dan bersenda gurau dengan teman pun terasa kurang memuaskan karena hanya melalui media sosial. Dari sinilah, semakin lama rasa jenuh tersebut menumpuk hingga menyebabkan stress yang mana juga berdampak terhadap pada kemampuan akademik mahasiswa, sehingga untuk itu diperlukan cara untuk mengatasi dan mengelola rasa stress tersebut sebelum semakin parah. Cara tersebut dapat berupa dengan melakukan coping stress, dan atau dengan menikmati waktu me time.
\end{abstract}

Kata kunci : stress, pandemi covid-19, mengelola stress

\section{ABSTRACT.}

Currently the world is experiencing an appalling condition where a virus known as Covid-19 is spreading so rapidly that it can kill many people regardless of age. Therefore, the government made a policy to carry out social distancing in order to control the spread of the virus, where people are encouraged to stay at home and do activities, both studying and working from home. While doing work from home, of course the community, without exception, students will eventually feel bored because they spend more time at home and rarely go out, even meeting and joking with friends feels unsatisfactory because only through social media. From here, the longer the feeling of boredom accumulates, causing stress which also affects students academic abilities, so that we need a way to deal with and manage the stress before it gets worse. This method can be in the form of coping with stress, and / or by enjoying the me time.

Keywords : stress, covid-19 pandemic, managing stress

\section{PENDAHULUAN}

Saat ini dunia sedang diguncangkan dengan adanya sebuah penyakit mematikan yang disebut dengan Covid-19, dimana penyakit ini disebabkan oleh suatu virus yang termasuk dalam golongan coronavirus yang bernama 
SARS-CoV-2 atau sering juga disebut dengan virus Corona. Virus ini awal mulanya terdeteksi muncul di Wuhan, Cina dan sekarang menyebar dengan cepat hingga ke berbagai penjuru dunia, tak terkecuali Indonesia sendiri. Kian hari pasien yang tertular Covid-19, baik yang masih dirawat atau telah meninggal dunia terus bertambah, meskipun pemerintah sudah menetapkan kebijakan untuk melakukan social distancing dan work from home, sebab bagaimanapun juga masyarakat harus tetap melakukan aktivitas di luar rumah dimana mereka harus membeli berbagai barang untuk kebutuhan sehari-hari. Virus ini sangat mudah menyebar sebab droplet dari penderita Covid-19 tidak dapat dilihat dengan mata telanjang dimana hal ini jugalah yang menyebabkan penyebaran virusnya cepat, sehingga sangatlah diharuskan untuk sering mencuci tangan, terlebih setelah berada di luar ruangan.

\section{Dengan semakin cepatnya} penyebaran virus, pemerintah pun menetapkan kebijakan agar masyarakatnya melakukan aktivitas seperti belajar dan bekerja melalui rumah. Dalam hal ini tak terkecuali mahasiswa juga harus melakukan aktivitas perkuliahannya melalui rumah secara daring. Aktivitas perkuliahan tersebut baik berupa kegiatan organisasi maupun kegiatan pembelajaran seperti pemberian materi dari dosen atau tugas diberikan secara online. Dikarenakan pandemi Covid-19 yang tidak mereda ini, pemeritah pun memperpanjang kebijakannya tersebut hingga diberitahukan info lebih lanjutnya dimana pasien Covid-19 berkurang jumlahnya namun hingga sekarang masih belum mendapatkan kepastian.

Selain itu, karena kondisi ini membuat mahasiswa harus berada di rumah terus-menerus, lama-kelamaan mereka mulai merasakan kejenuhan karena aktivitas yang monoton. Meskipun sebagai mahasiswa di era modern yang mana teknologinya juga memadai, tidak menutup kemungkinan bahwa tingkat stress mereka pun juga semakin meningkat. Ditambah dengan kegiatan perkuliahan yang meskipun dilakukan secara online bisa dikatakan lebih mudah, namun tetap saja ada kekurangannya.

\section{METODOLOGI PENELITIAN}

Dalam hal ini, penulis sebagai seorang mahasiswa tentunya juga mendapatkan tugas untuk menulis sebuah artikel guna mendapatkan pengalaman dan menambah pengetahuan, serta untuk memenuhi nilai dari tugas yang diberikan oleh dosen. Dalam melakukan penelitiannya, dikarenakan kondisi yang tidak memungkinkan maka penulis pun menggunakan metode penelitian berupa kajian literatur, dimana penulis menemukan informasi dengan cara meneliti dan memahami buku-buku serta dokumen atau sumber tertulis lainnya. Selain itu juga, penulis juga mendapatkan berbagai informasi terkait penulisan artikel ini melalui pengalaman dalam kehidupan pribadi, yang mana penulis juga menggunakan sudut pandang dari dirinya sendiri dan sudut pandang dari pihak ketiga.

\section{HASIL DAN PEMBAHASAN}

Dalam penelitiannya, penulis menemukan bahwa di masa pandemi ini mahasiswa memang mengalami kondisi yang cukup sulit, terlebih jika ia merupakan mahasiswa yang merantau dan harus mengkos serta jauh dari keluarga yang disayangi, sehingga hal ini bisa saja berpengaruh terhadap caranya mengelola emosi. Adanya banyak tugas kuliah yang diberikan oleh dosen juga membuat mahasiswa sebenarnya tambah stress, terlebih jika kuota yang dimiliki tiba-tiba habis saat tengah mengerjakan tugas, dan uang yang dimiliki tidak cukup. Selain itu pula, dengan bertambahnya rasa stress yang dirasakan oleh mahasiswa, penulis 
merasa bahwa rasa kepercayaan diri mahasiswa juga akan mengalami penurunan karena selain rasa stress tersebut membuatnya sulit untuk mengerjakan tugas sehari-hari juga berdampak pada caranya berinteraksi dengan teman-temannya meskipun dilakukan secara daring.

Dalam hal ini, penulis menemukan bahwa sebenarnya terdapat banyak hal yang sebenarnya bisa dilakukan agar dapat mengurangi rasa stress tersebut. Beberapa hal diantaranya adalah dengan melakukan interaksi dengan teman-teman, meskipun dilakukan secara online tetapi tetap ada baiknya jika ketika sudah merasakan stress maka ia mencurahkannya walau memiliki teman yang sedikit namun bisa benarbenar dipercaya dan mampu memberikan saran serta mendengarkan dengan baik. Penulis merasa jika stress yang dirasakan sudah terlalu berat, maka sebaiknya segeralah berkonsultasi kepada psikolog yang memang lebih andal dan profesional dibidangnya.

Selain itu, penulis sebenarnya juga menemukan bahwa untuk melakukan coping stress itu sendiri juga bisa dilakukan dengan sendirian seperti melakukan me time. Coping stress ini sendiri memang dilakukan untuk mengurangi rasa stress yang dialami, sehingga dapat mengurangi pengaruh stress yang dialami terhadap kegiatan sehari-hari. Me time itu sendiri juga sebenarnya dilakukan dengan menghabiskan waktu sendirian namun waktu yang dihabiskan tersebut bersifat produktif namun menyenangkan sehingga tidak merasakan stress.

Dalam hal ini, penulis berpendapat bahwa melakukan me time seperti dengan membaca buku, mendengarkan musik, menonton film, atau melakukan hobi lainnya bisa mengurangi rasa stress. Terlebih di era modern seperti sekarang ini, dengan adanya teknologi yang maju dan jaringan internet yang tesedia dimanapun dan kapanpun tentu tidak sulit untuk menemukan berbagai hiburan lainnya, seperti menonton anime atau menonton drama korea yang saat ini memang digemari oleh berbagai kalangan baik itu remaja maupun dewasa, tak terkecuali mahasiswa juga.

Disisi lain, dikarenakan kondisi yang mengharuskan untuk melakukan aktivitas melalui rumah, saat ini belanja secara online banyak digemari oleh masyarakat. Selain itu juga, banyak orang yang menghabiskan waktunya secara online seperti nemainkan media sosialnya, namun dari situlah mereka jadi merasa kecanduan bahkan hingga menjadi konsumtif. Sehingga dalam hal ini ada baiknya untuk selain mengelola emosi dan rasa stress juga mengelola waktu dan keuangannya dengan teratur.

Selain itu pula di masa seperti ini yang mengharuskan untuk tetap berada di rumah, tidak menutup kemungkinan dari adanya rasa stress yang bertambah akan membuat seseorang mengalami gangguan psikologis. Dalam hal ini penulis menemukan bahwa karena terlalu lama berada di rumah, seseorang dapat saja mengalami gangguan psikologi, yang mana paling sering ditemukan pada remaja ialah sef-harm, sehingga untuk mencegahnya maka benar-benar diperlukan coping stress itu tadi, namun jika dirasa stress tersebut tidak berkurang maka bisa segera menghubungi bantuan dari seseorang profesional dibidangnya seperti psikolog, atau mungkin bisa saja terlebih dahulu menceritakannya dengan teman yang memang benar-benar dipercaya, atau jika bisa maka berceritalah kepada keluarga karena bagaimanapun juga keluarga merupakan orang yang paling dekat dengan kita teruatama keluarga yang serumah.

Selain kecenderungan mengalami sef-harm, penulis juga berpendapat bahwa terdapat kecenderungan adanya eating disorder atau gangguan makan. Hal ini 
dikarenakan kurangnya melakukan aktivitas di luar ruangan seperti olahraga, namun mengalami peningkatan dalam mengonsumsi makanan berlemak tinggi sehingga adanya rasa bersalah dan khawatir jika terjadi peningkatan berat badan. Dari sinilah mereka akan rela melakukan diet baik itu yang ringan hingga ekstrem demi mengembalikan bentuk tubuh ideal, walau sebenarnya tubuh mereka baik-baik saja tetapi persepsi mereka berbeda. Disisi lain juga terdapat mahasiswa yang sebenarnya merasa tubuhnya masih sama seperti biasa, namun perubahan selera makan hingga menjadi jarang makan juga terjadi, yang mana hal ini bisa saja dikarenakan adanya rasa malas atau karena terlalu asik dengan dunianya atau terlalu sibuk dengan tugasnya hingga lupa makan.

\section{KESIMPULAN}

Dalam hal ini, sebagai seorang mahasiswa tidak akan terlepas dari yang namanya tugas. Berbeda dengan di waktu sebelum pandemi Covid-19 menyerang, para mahasiswa di era new normal ini diberikan tugas dari dosen secara online, yang mana sebenarnya hal ini mempermudah pengerajaannya, namun di satu sisi sebenarnya terdapat kekurangan yang sangat besar. Kekurangan itu ialah jaringan, kuota, dan perangkat yang memadai. Sehingga sering kali mahasiswa mengeluh dikarenakan hal-hal yang disebutkan penulis tadi.

Selain itu, semakin lama berada di rumah, tentu seseorang akan merasa semakin bosan karena tidak ada teman yang dapat diajak bercanda, dan meskipun ada juga hanya dapat bertemu secara online karena kondisi yang tidak memungkinkan untuk bertemu. Mungkin bagi mahasiswa yang masih tinggal bersama dengan keluarganya tidak terlalu merasakan rasa kesepian tersebut karena masih berkumpul dengan orang yang disayangi, namun hal ini berbeda bagi mereka yang merantau dan harus mengkos, ditambah jika mereka tinggal di zona merah akan semakin sulit untuk bisa berkumpul kembali dengan keluarga karena faktor wilayah yang berbeda.

Dalam situasi yang mengharuskan untuk tetap berada di rumah ini, mungkin bagi seorang introvert hal ini tidaklah terlalu sulit sebab tidak mengharuskannya untuk melakukan tatap muka yang mana bagi para introvert merupakan kegiatan yang menguras tenaga. Disatu sisi bagi para ekstrovert hal ini sangatlah tidak mengenakkan sebab tidak dapat berinteraksi secara langsung dengan teman-temannya. Namun tetap saja, sebagai seorang manusia yang merupakan makhluk sosial tentu harus melakukan interaksi dengan orang sekitarnya sebab manusia tidak dapat melakukan segala sesuatunya dengan sendirian.

Selain itu, semakin lama seseorang berada di satu tempat yang sama, ditambah jika ia sendirian, maka seseorang tersebut tentunya semakin lama juga akan semakin tambah merasakan stress. Dari rasa stress tersebut, ada kecenderungan bahwa hal tersebut akan berdampak terhadap aktivitas yang dilakukan sehari-harinya. Rasa stress juga dapat berdampak terhadap kemampuan akademiknya, sehingga untuk itu diperlukanlah cara untuk bisa mengendalikan rasa stress itu sehingga tidak berdampak pada aktivitas sehari-hari.

Oleh karena itu, diperlukanlah adanya strategi coping stress sehingga mahasiswa tidak mengalami stress berlebihan selama masa pandemi, entah itu dengan melakukan me time dengan mengerjakan hobi atau aktivitas yang disukai, atau dengan berkumpul dan bercengkerama dengan keluarga atau teman. Sebab rasa stress yang berlebihan biasanya akan berujung dengan melakukan self-harm, terutama jika tidak bisa mengendalikan emosi nya dengan baik, sehingga untuk hal ini apabila sudah merasakan stress yang berlebihan maka 
sebenarnya disarankan untuk menghubungi psikolog yang memang sudah profesional dibidangnya.

\section{V.SARAN}

Dalam pembuatan artikel ini, penulis menemukan bahwa dalam hal menulis tidaklah sulit jika dalam menulis itu tidak tergesa-gesa dan dilakukan dengan tenang. Penulis juga merasa bahwa sebagai seorang mahasiswa yang baru pertama kali membuat artikel ilmiah mungkin terdapat banyak kesalahan dalam pembuatannya, sehingga penulis memohon maaf apabila tulisan ini masih berantakan. Namun sebagai seorang penulis pula, izinkan saya memberikan beberapa saran terkait permasalahan yang diangkat dalam penulisan artikel ini.

Alangkah baiknya, dalam mengatasi rasa stress dilakukan dengan cara yang produktif atau menghasilkan sesuatu baik berupa karya ataupun materi, sebab dalam kondisi pandemi ini juga sulit untuk mencari uang, padahal disisi lain kebutuhan akan semakin bertambah banyak. Selain itu pula, penulis juga menyarankan agar selain mengelola emosi juga mengelola waktu dan keuangannya, serta di masa pandemi seperti ini juga sangat disarankan untuk selalu menjaga kebersihan dan kesehatan badan baik dengan olahraga dan rajin mencuci tangan dengan sabun dan mandi secara teratur, sebab virus Covid-19 yang saat ini menyebar dengan cepat ke berbagai dunia ini menularkan ke berbagai orang tanpa memandang usia, gender, ataupun ras dan budaya.

\section{DAFTAR PUSTAKA}

Abbas, E. W. (2020). Menulis di Otak dan Menuliskan Tulisan di Otak.

Abbas, E. W. (2020). Menulis Mudah, Menulis Ala Ersis Writing Theory.
Abbas, E. W., \& Erlyani, N. (2020). Menulis di Kala Badai Covid-19.

Amini, M., Mayangsari, M. D., \& Zwagery, R. V. (2020). Hubungan antara Kemandirian Belajar dengan Komitmen Tugas pada Mahasiswa Program Studi Psikologi. Jurnal Kognisia: Jurnal Mahasiswa Psikologi Online, 2(2), 149-152.

Apsari, L., Mayangsari, M. D., \& Erlyani, N. (2017). Pengaruh Perilaku Modeling pada Tayangan Drama Korea terhadap Citra Diri Remaja Penggemar Drama Korea. Jurnal Ecopsy, 3(3).

Aridarmaputri, G. S., Akbar, S. N., \& Yuniarrahmah, E. (2016). Pengaruh jejaring sosial terhadap kebutuhan afiliasi remaja di program Studi Psikologi Fakultas Kedokteran Universitas Lambung Mangkurat. Jurnal Ecopsy, 3(1).

Hafifah, D. N., Febriana, S. K. T., \& Fauzia, R. (2016). Efektivitas Pendampingan Psikologi dengan Metode Appreciative Inquiry untuk Meningkatkan Kepercayaan Diri. Jurnal Ecopsy, 2(3).

Maihayana, M., Anward, H. H., \& Mayangsari, M. D. (2020). PERBEDAAN KESESAKAN PADA MAHASISWA FAKULTAS KEDOKTERAN (PSIKOLOGI, ILMU KEPERAWATAN, KESEHATAN MASYARAKAT) YANG TINGGAL DI RUMAH SENDIRI, TINGGAL DI KOS DAN TINGGAL DI ASRAMA DI BANJARBARU. Kognisia prodi Psikologi FK ULM, 2(2), 25-36.

Putri, C. P., Mayangsari, M. D., \& Rusli, R. (2020). PENGARUH STRES AKADEMIK TERHADAP ACADEMIC HELP SEEKING PADA MAHASISWA 
PSIKOLOGI UNLAM DENGAN

INDEKS

PRESTASI

KUMULATIF

RENDAH.

Kognisia prodi Psikologi FK ULM,

1(2), 28-37.

Regina, A., Istiqomah, E., \& Zwagery, R. V. (2020). HUBUNGAN STRATEGI COPING YANG BERFOKUS PADA EMOSI DENGAN BURNOUT BELAJAR PADA MAHASISWA PROGRAM STUDI KEPERAWATAN FAKULTAS KEDOKTERAN UNIVERSITAS LAMBUNG MANGKURAT BANJARBARU. Kognisia prodi Psikologi FK ULM, 2(2), 7-12.

Rizky, L., Erlyani, N., \& Akbar, S. N. (2020). HUBUNGAN ANTARA KEBUTUHAN

DENGAN PENGELOLAAN KESAN PADA REMAJA PENGGUNA MEDIA SOSIAL INSTAGRAM DI SMA NEGERI 2 BANJARBARU. Kognisia prodi Psikologi FK ULM, 1(1), 68-75.

Santoso, M. V., Fauzia, R., \& Rusli, R. (2020). HUBUNGAN ANTARA KEPUASAN CITRA TUBUH DENGAN KECENDERUNGAN BODY DYSMORPHIC DISORDER PADA WANITA DEWASA AWAL DI KOTA BANJARBARU. Kognisia prodi Psikologi FK ULM, 2(1), 55-60.

Virgandiri, S., Lestari, D. R., \& Zwagery, R. V. (2020). RELATIONSHIP OF BODY IMAGE WITH EATING DISORDER IN FEMALE ADOLESCENT. Jurnal Ilmu Keperawatan: Journal of Nursing Science, 8(1), 53-59.

WARMANSYAH ABBAS, E. R. S. I. S. (2020). Menulis di Era Covid-19: Memanage Trauma Psikologis Menghindari Psikosomatis.
Menulis di Era Covid-19: Memanage Trauma Psikologis Menghindari Psikosomatis. 